\title{
Design on College English Teaching Reform Mode Based on Information Technology
}

\author{
Yongyan Song \\ School of Foreign Languages \\ Jilin Agricultural University (JLAU) \\ Changchun 130118, China \\ Email: 1012932249@qq.com
}

\begin{abstract}
The purpose of this paper is to put forward the suggestion on how to design the college English teaching reform mode based on information technology. Innovative point of the college English teaching reform is compression of the theme course and increase of application in practice. In order to make the reform be carried out smoothly, the teaching mode has been improved by means of opening optional courses including four modules: practical English skill, advanced English, general education and general academic English. The theme course and the four modules are organically integrated by using information technology in classroom teaching, practical teaching, teaching assessment etc. The result is that the teaching effect is good and students' application ability has been increased. Therefore, the college English teaching reform mode is suitable for the students in our university and will be widely used in the future.
\end{abstract}

Keywords-Information technology; College English; Optional course; Teaching reform mode

\section{INTRODUCTION}

A new round of college English teaching reform is imperative accompanied by foreign language entrance examination reform. The new round of college English teaching reform of our university was kicked off. Innovative point of the reform is compression of theory class and increase of practice, including speech, dubbing, drama etc. In order to solve the problem of the compression of theme course content, four optional modules will be opened, including practical English skills ( English audio-visual and college English translation and writing), advanced English (advanced English reading, advanced English skill training), general education (English national cultural studies, literature review) and general academic English (agricultural science, agricultural science and technology English reading, translation and writing of English). Based on the characteristic of this reform, this study proposes the college English teaching reform mode based on information technology. The nineteenth chapter of the outline of the national program for medium and long term educational reform and development (years 2010-2020) [1] pointed out information technology has a revolutionary impact on the development of education, which was paid great attention to in 2010. The educational informationization should be integrated into the overall strategy of national informationization development, and the educational information network should be planed in advance. From the strategic point of view, the important position of information technology application in education should be established. In 2012, “ ten year development plan of educational informationization (years 2010-2020 )" formulated by the Ministry of Education [2] pointed out that we should give full play to the guiding role of education informatization to support the development and lead the innovation in the process of building a learning society and building a powerful country of human resources. The revolutionary impact of information technology on education is transformation, not revolution, which requires that we should continue to explore the integration of information technology and education, adhere to the application oriented, adhere to the mechanism of innovation. This shows the important position of information technology in teaching, which has been fully embodied in the reform of college English teaching.

\section{INFORMATION TECHNOLOGY}

Information technology has a wide range of meanings and is still evolving, so it is difficult to give an exact definition. At present, there are not less than 100 definitions of information technology. In a broad sense, information technology is a general term for various technologies that can extend the functions of human information organs. It is a collection of information related to the production, acquisition, detection, identification, transformation, delivery, processing, storage, display, control, utilization and feedback of information. In a narrow sense, information technology refers to the collection, storage, processing, dissemination and application of information [3]. The information technology system includes basic technology, support technology, main technology and application technology [4].

\section{A NEW ROUND OF COLLEGE ENGLISH TEACHING REFORM}

College English teaching is an organic component of higher education. College English curriculum is a required basic course for college students. College English is the teaching system of a variety of teaching modes and teaching methods based on English language knowledge and application skills, learning strategies and intercultural communication as the main content, and the foreign language teaching theory as a guide. The goal of College English teaching is to train students' comprehensive ability in English, especially listening and speaking ability, which can make them oral and written communication effectively in the future work and socialization, at the same time enhancing their autonomous learning ability, 
improving the comprehensive cultural qualities to meet the needs of social development and international exchanges [5]. In order to achieve the goal of college English teaching, the current round of teaching reform has reduced the hours of classroom teaching and increased the hours of practical teaching, which enable students to apply what they have learned to practice.

\section{A. Curriculum Setting}

Before the reform, college English teaching plan has been arranged according to the traditional class schedule with four semesters, including freshman year and sophomore year, totaling 280 class hours. According to the latest English teaching reform program, college English teaching class hours will be reduced from the original 280 class hours to 192 class hours. Graded teaching has been implemented in our university in accordance with the general requirement, higher requirement and higher requirement of college English course. In order to meet the needs of students in different levels and different majors to learn English, college English teaching process is divided into basic comprehensive stage and improving special stage. Teaching content mainly is New Horizon College English: Reading and Writing books 1-4 published by FOREIGN LANGUAGE TEACHING AND RESEARCH PRESS and New Century College English: listening and speaking books 1-4 published by Shanghai Foreign Language Education Press in the basic comprehensive stage. Optional courses of four modules are set up, including practical skills, advanced English, general education and general academic English in the improving special stage. Although the teaching objectives are different in the two stages, they are connected with each other. In different stages, in order to benefit students' personality training and development, different modular courses will be opened according to the levels and interests of students [6].

\section{B. Classroom Teaching Based on Multimedia Technology}

Multimedia technology has changed the way of outputting the teaching information, which increases the amount of information in class and greatly enriches the teaching content. Using multimedia projection, teachers can combine drawing, text, sound and shape to show the dynamic change process, image and intuitive demonstration experiment to reproduce the three-dimensional effect. Thus, the students' impression and memory will be deepened, and the interest of learning will be stimulated to break through the key points and difficulties in teaching to achieve the best teaching effect [7]. Under the premise that the class hours are compressed and the teaching efficiency is improved, teachers should apply modern educational technology or multimedia technology to teaching, the most obvious advantage of which is that the teaching information that can be delivered in unit time has significantly increased. Therefore, in making new teaching plan, we can reduce the class hours on the condition that the teaching content is not compressed or even increased [8]. This requires teachers to make full use of multimedia technology, and fully display the teaching content in the form of text, images, sounds, videos, animations, and so on to keep the teaching content scientific, novel, systematic and comprehensive etc [9]. Through this teaching mode teachers can make use of large amount and capacity of multimedia information to save space and time and improve teaching efficiency [10].

The 192 class hours after the compression are assigned to four semesters, 48 class hours each semester, of which 12 class hours are used for listening and speaking, 4 class hours are used for unit tests and only 32 class hours are used for reading and writing. How to make full use of 32 class hours? Take the first book of New Horizon College English (reading and writing) as an example, there are 10 units in this book, and each unit is divided into two parts: Section A and Section B. Each part contains a text and related exercises. It is almost impossible to complete all the contents of a book in 32 class hours. For this reason, according to the unit theme, the content of the book is divided into two blocks, one is the 5 units taught in the classroom, and the other is the 5 units self- studied after class. For classroom teaching, the number of class hours that can be used is assigned to one unit. Seven class hours are used in text A, such as one class hour for words and expression, four class hours for the text, two class hours for the exercises, and three class hours are used for text B, such as one class hour for words and expressions, one class hour for the text, half class hour for the exercises and half class hour for reading skills.

\section{Practice Teaching Based on Network}

With the rapid development and spread of network technology, network resources are more and more abundant such as Pt listening network which offers BBC, VOA, ABC CRI, Discovery, FM961 and other Internet radio stations for the learners to practise listening, hjenglish.com, which is a comprehensive English website including test information, training information and English community etc. English writing network, the main columns of which include grammar, applied writing, test writing, background culture and appreciation of master pieces [11]. For the 5 units of selfstudied after class, this part requires students to make use of the network characteristics of low cost and wide benefit to optimize the allocation of teaching resources effectively, and realize the effective supplement to the teaching of college English class. Network practice teaching can solve the problem that the course content can not be increased because of the lack of class hours, the shortage of teachers and funds and so on [12]. Therefore, the teaching task requires students to use their information technology application ability to apply the language knowledge they have learned with the help of the network. Based on the topic of autonomous learning, the students adapt the content of the unit into a script with the help of network resources, each study group makes a short play based on the script adapted, posts the works online, appreciates and assesses the works among the groups to achieve the purpose of inter group information sharing. Students can use email, BBS, QQ and Blog to express their ideas and communicate with each other [13]. Therefore, students can improve their autonomous learning ability by means of acquisition of information, arrangement of information, processing of information, innovation and utilization of information, dissemination of information and sharing of information. In addition, teachers can recommend some network resources for students to learn and require students to set aside a certain period of time to learn English online, and 
take notes such as writing key words, main ideas, rewriting etc, therefore, students can improve their English.

In order to support foreign language teaching reform, our university has built the platform of www.pigai.org and www.longmanenglish.cn. Students can register in www.pigai.org, and finish the writing assignment given by the teacher, and then they can get grades on the net, if they are not satisfied with the grades they can correct the writing until they are satisfied, after correcting the students can improve their writing levels. The number of my students is 127 and $62.8 \%$ of them correct their writing more than 12 times, which is helpful to improve their writing ability. In addition, students can make full use of www.longmanenglish.cn to improve their comprehensive ability. In order to solve the problems that students have during learning on www.longmanenglish.cn and check what they have learned, the teacher would organize the students to deal with the problems face to face and require students to present what they have learned, which can integrate classroom learning and online learning, resulting in good teaching effect.

\section{Teaching Assessment Based on Information Application Technology}

Modern information technology and Internet technology construct network teaching platform which can not only provide college students with a large number of abundant and informative English learning materials, it can also be applied to teaching assessment. Teaching assessment is an important part of college English teaching. A comprehensive, objective, scientific and accurate assessment system is essential to achieve the teaching objectives [14]. The assessment of college English is still a combination of formative assessment and summative assessment. However, in the new round of college English teaching reform, both of them account for $50 \%$ respectively. Then, how to achieve the formative assessment of $50 \%$ is the highlight and important point of the current college English teaching reform. In view of the three parts of attendance, homework and class performance, the teacher continues to assess and record his performance, however, for the part of language testing, teachers can organize simultaneous testing of several classrooms on the local area network, and students can implement paperless testing on the computer without networking. For the highest percentage of autonomous learning out of formative assessment, teachers should make full use of the teaching management module on the network platform in the New Horizon College English (Second Edition) to organize teaching assessment. The assessment process on Internet is to implement self-assessment, evaluation among students and evaluation by teachers etc. [15]. Autonomous learning assessment mode based on Internet is that teaching assessment based on Internet includes student self-assessment, assessment among students and teacher assessment.

\section{E. Optional Modules Based on Network and Multimedia.}

Opening optional courses in college English teaching is keeping pace with the times and the inevitable requirement and product of the development of foreign language teaching [16]. English optional courses are based on English knowledge, which aims at stimulating students' interest in learning and cultivating students' special skills. The development of optional courses has undoubtedly given a new lease of life into English teaching, and has created a colorful English learning platform for students in English teaching reform. Four optional modules will be opened in our university according to the different requirements of different stages. Setting of college English optional courses is as follows, four optional modules includes practical skills (speaking and listening, translation and writing), advanced English (advanced English reading, advanced English skill training), general education (seminar on English national culture, introduction to English and American literature) and universal academic English (agricultural sci-tech English reading, agricultural sci-tech English translation).

According to the students' requirements in different learning stages, English optional courses are offered in four modules during the four years' college life. In the first semester, dubbing course and audio-visual course are opened, in the second semester, drama course and speech course are opened. After learning for one year in the university, students can improve their English a lot. Therefore, in the third semester, translation and writing, advanced English reading and advanced English skill training are opened, and in the fourth semester, seminar on English national culture and introduction to English and American literature are opened. After two years' study in the university, students begin to learn professional courses, therefore, agricultural sci-tech English reading and agricultural sci-tech English translation are opened in this stage. All in all, optional courses are opened through the students' learning process in the university.

According to the credit management system and optional courses, usually finishing each course needs 24 or 32 class hours. The optional course has the characteristics of fewer hours, strenuous teaching tasks and large number of students, therefore, the experiment and reform of new college English teaching mode is carried out by foreign language teachers, using network as the media, the campus network as support, network teaching platform for college English as substratum, network textbooks as content with the teachers to use the multimedia teaching. The teacher-centered classroom teaching mode will be improved by making full use of multimedia, network technology. English teaching will not be restricted by time and place. It will develop towards individualized learning and autonomous learning, and cultivate all kinds of talents to meet the needs of society. 


\section{CONCLUSION}

A new round of College English teaching reform in our university is characterized by compressing class hours and increasing practical skill training. Under the premise of class hour compression, we should improve the teaching level of foreign languages at the same time we should improve students' practical application ability, which is a new challenge for foreign language teachers. In order to meet the challenge better and make the teaching reform successful, the current reform needs to start with the information technology that can be relied on so that information technology itself becomes an important part of teaching. Proficiency in multimedia technology and network information technology will be beneficial to the smooth progress of the reform so as to achieve the purpose of the training of students' comprehensive application ability in English, especially listening and speaking ability. Therefore, students can use English to communicate effectively in the future study, work and social activities, also can enhance their self-learning ability and improve the comprehensive cultural quality to meet the needs of China's social development and international exchanges. This college English teaching reform mode has been successful and suitable for the students in our university and will be widely used in the future.

\section{REFERENCES}

[1] Information http://www.moe.gov.cn/publicfiles/business/htmlfiles/moe/s3342/. on Chinese)

[2] Information on http://www.gov.cn/jrzg/. (In Chinese)

[3] Information on http://blog.sina.com.cn/s/blog_4b18593901009i7r.html 200807 10/. (In Chinese)

[4] Information http://its.nbtvu.net.cn/xhyu/is_cai/chapter03/section1/11.htm (In Chinese)

[5] Department of higher education of the Ministry of Education: College English Curriculum Requirements, Higher Education Press, China, p.1, 2007. (In Chinese)

[6] Information on http://news.hexun.com/2013-09-20/158171200.html. (In Chinese)

[7] .Z. Xu, How to Utilize Multimedia technology to Improve the Quality of Classroom Teaching [J]. JOUR NAL OF XI AN UNIVERSITY OF POST AND TELECOMMUNICATIONS, Vol. 14, pp. 164-166, 170, Jan. 2009. (In Chinese)

[8] X.L. Zhang and L. Jiang, On the Promotion of University Teachers' LInformation Level[J]. Maritime Education Research, pp. 82-84., February. 2006. (In Chinese)

[9] Y.F. Han, On the Significance of Improving College Teachers' Application Ability of Information Technology[J]. Science \& Technology Information, p.75. No. 35, 2006. (In Chinese)

[10] X.Q. Liu, How to Use Multimedia Technology in History Teaching[J]. Education for Chinese After-school(Theory), p.565, August 2009. (In Chinese)

[11] Information on http://www.e2say.com/blog/post/yingyuxuexiwang.html (In Chinese)

[12] Q. Huang, Improving College students' Comprehensive English Ability Using Network Technology[J]. Jiangxi Educational Research, p. 58., August 2005. (In Chinese)

[13] Information http://wenku.baidu.com/view/40ed1285d4d8d15abe234ef0.html. (In Chinese)

[14] W.X. Zhang, Application of Formative Assessment in College English Intensive Reading Teaching[J]. JOURNAL OF JIXI UNIVERSTIY, pp. 88-89, 94, March 2012. (In Chinese)

[15] S.T. Zheng, NEW HORIZON COLLEGE ENGLISH Reading and Writing(second edition) Book 2[M]. FOREIGN LANGUAGE TEACHING AND RESEARCH PRESS, p. iii, 2008.(In Chinese)

[16] H.Y. Nan and C. Li, Probe into the Teaching Mode of College English Optional Course [J]. China Adult Education, pp.181-182, January 2007.(In Chinese) 